\title{
AOR
}

Selected Papers of \#AolR2021:

The 22nd Annual Conference of the

Association of Internet Researchers

Virtual Event / 13-16 Oct 2021

\section{TRANSNATIONAL FEELINGS: DIGITAL AFFECT AS A GLOBAL ANALYTIC}

\author{
Heather Jaber \\ University of Pennsylvania \\ Marwan Kraidy \\ Northwestern University Qatar \\ Omar Al-Ghazzi \\ London School of Economics and Political Science \\ Sulafa Zidani \\ Massachusetts Institute of Technology

\section{Introductory Statement}

This panel examines the role of affect in transnational digital media, offering finegrained analyses of online communities and media artifacts which contend with and carve out contested futures. Across several sites and languages, these papers reflect on the role of feeling in the formation of new publics, communities, and identities, illuminating the suturing and severing work of digitally mediated affects. Using a variety of humanistic and qualitative approaches, this panel mines affects which are steered, channeled, and recoded to challenge hegemonic practices of meaning-making. They offer that in a moment of global ruptures-lost visions of revolution, polarizing extremist expressions, and uncertain socioeconomic conditions-digital affect is an analytic for contending with interdependent realities.

In the last decade, scholarly work in media and communication has turned to affect theory to complicate functionalist models of power, liberal notions of the sovereign self, and an overdetermination of the causative power afforded to language. This work has drawn on a range of theories of affect and emotion (Ahmed 2014, Gregg \& Seigworth 2010, Massumi 2002) to examine the rise of networked publics (Papacharissi 2015), new media practices (Chun 2016), and the weaponization of affect in digital media (Boler \& Davis 2021). Beyond the walls of the academy, popular discourse has also designated this as a particularly affective time (Hsu 2019), turning to affect to answer questions about our increasingly complex entanglements with digital media.

Suggested Citation (APA): Jaber, H., Kraidy, M., Al-Ghazzi, O., Zidani, S. (2021, October). Transnational Feelings: Digital Affect as Global Analytic. Panel presented at AolR 2021: The 22nd Annual Conference of the Association of Internet Researchers. Virtual Event: AoIR. Retrieved from http://spir.aoir.org. 
At the same time, while the "affective turn" has offered new ways of examining contingency and causality, it has remained difficult to distinguish the particular power(s) of affects and to trace what is often described as intangible, ephemeral, and lying beyond the level of signification. In order to think through the power of digital affect, this panel turns to several transnational and transhistorical contact zones to reanimate questions of feeling on the Internet. It examines the power of particular affectsnostalgia, fear, shame, and zanaakha, a kitschy humor of the times-and the particular power of affects - to recode undesirable and threatening feelings, to suture continuities with the past, and to relieve the pressures of a fraught present.

Through qualitative interviews, close readings, and textual analyses, these projects engage in a range of approaches to trace the affects which circulate online. Across these papers, sites of mediation include the live-streamed media event, meme-making and historically focused social media accounts, and the promotional materials of extremist groups. Sites like the World Economic Forum allow audiences to vent shared frustrations toward national representatives who escape local censure. On Twitter, national affects become transnational, illuminating shared affinities which can form the basis of new identifications while also entrenching nationalist responses to international censure. At times, such affects are sought out and manipulated, with groups like the one that calls itself "Islamic State" utilizing the digital to potently recode symbols of fun into evil and symbols of pain into symbols of healing. Propagandistic images not only represent extremist expression but bind and polarize worldviews. However, alternative, more reparative uses of digital media produce other ways of imagining community. AlAndalus, the Arabic name for the Muslim-ruled Spain of 711-1492, becomes a node in the production of a new Arab Muslim identity, generating new ways of feeling history. Here, digital mediation of the past offers those yearning for respite and hope ways of contending with the present and making it mean differently. These are present in the transnational "structures of feeling" (Williams 1977) that meme-makers around the world illuminate through their use of humor and critique. These continuities point to shared affinities across language and nation, making a transnational approach to questions of affect politically productive.

Each of these projects contends with not only imagined futures but presents which are inescapably interdependent. Across each site, new kinds of "worlding" take place, even when these worlds may be radically at odds with one another. By turning to these spaces, these projects make the case for careful, contextualized approaches to affect and digital media in order to mine their political power.

\section{References}

Ahmed, S. (2014). The cultural politics of emotion (Second edition). Edinburgh University Press.

Boler, M., \& Davis, E. (Eds.). (2021). Affective politics of digital media: Propaganda by other means. Routledge. 
Chun, W. H. K. (2016). Updating to remain the same: Habitual new media. The MIT Press.

Gregg, M., \& Seigworth, G. J. (Eds.). (2010). The affect theory reader. Duke University Press.

Hsu, H. (2019, March 18). Affect theory and the new age of anxiety. The New Yorker. https://www.newyorker.com/magazine/2019/03/25/affect-theory-and-the-new-age-ofanxiety

Massumi, B. (2002). Parables for the virtual: Movement, affect, sensation. Duke University Press.

Papacharissi, Z. (2015). Affective publics: Sentiment, technology, and politics. Oxford University Press.

Williams, R. (1977). Marxism and Literature. New York: Oxford University Press. 


\section{DIGNITY AND SHAME IN TRANSNATIONAL SPECTACLES OF JUSTICE}

Heather Jaber

University of Pennsylvania

This paper examines affective economies of pleasure and shame which undergird spectacles of transnational capital like the World Economic Forum (WEF). It offers as a case study the 2020 WEF in Davos, Switzerland for the way that it provoked digital commentary around national representation by a Lebanese public on the heels of a revolution. In particular, I turn to a panel entitled "The Return of Arab Unrest" for the way that affects of pleasure and shame were channeled and recoded by panelists and viewers. I offer that by turning to the political work that particular emotions do, we have better tools to understand the nationalist responses which have surfaced following national mobilizations not only in Lebanon, but across the world. What is more, turning to the WEF as a node in transnational circuits of capital prompts renewed questions of independence and interdependence of not only nations, but of the affective states of transnational publics.

The annual invite-only event which gathered the global elite-corporate leaders, politicians, media moguls, NGO directors, and select academics-made headlines across the country due to the controversy that erupted around the presence of one of Lebanon's most notorious political actors, Gebran Bassil. Bassil was not only the leader of the largest Christian bloc of Lebanese parliament, but the son-in-law of Lebanon's president and had lauded a host of ministerial positions in the years past. In the context of mass mobilizations that had erupted on October 17, 2019, Bassil's was one of several names chanted in calls for the downfall of the ruling regime. An online petition by Lebanese diaspora circulated, asking organizers to remove him from the line-up. However, Bassil was not disinvited and the event became an anticipated one after CNBC International correspondent Hadley Gamble's questioning of Bassil became something of a spectacle for its performative dimension. In particular, the panel was distinct and heavily discussed online for its moralizing element, whereby Lebanon, through Bassil, was castigated for its economic failure.

The "affective turn" has led to an interest in examining affect, emotion, and feeling in the field of communication, with much work drawing on the Deleuzian-Massumian dialect which conceptualizes affect as a pre-subjective force distinct from emotion (Clough 2018, Manning 2013). An alternative strand adopts a looser typology of affect and emotion (Schaefer 2020), situating itself amongst scholars in queer and feminist theory, religious studies, and poststructuralism (Ahmed 2014, Schaefer 2015). This project follows this second strand, offering that an understanding of particular affects and emotions offer more political utility and analytic potential for the study of digital media. By adopting this orientation, we are able to think through the particular ways we are differently moved by what I call the "transnational spectacle of justice." Rather than adopting a view of the Internet as a site for the circulation of a monolithic Affect, this project turns to the way that such sites rechannel, reroute, and recode affects like pleasure, shame, joy, and humiliation. 
In particular, I am interested in the ways that such spectacles figure as sites where internal contradictions are discursively disguised, but affectively resonant. While all panelists denounced the regressive role of emotion in voting habits in the MENA region, putting forth a secular discourse of a rational public sphere, they acted as channelers of different emotions. The pleasure of such call-outs-by indignant diaspora, international funders, and transnational media figures-undergirds much of the online discourse around the event. I examine the performative effects of such callouts, such as the performances of dignity, pride, and shame of those interpellated by the spectacle.

In order to discern the different affects which were channeled through this site, I examine the live-streamed spectacle, press around the event, and responses on Twitter. I turn to the posts by social media users who shared a variety of memes, jokes, expressions of indignation, and other commentary about the event. In doing so, I build on work which examines the affective dimensions of digital media (Chun 2016, El-Ariss 2019, Papacharissi 2015, Schaefer 2020), seeking to animate studies of the Internet with attention to particular feeling states. I build on this work to recognize the ways that affects like pleasure and shame reveal interdependencies and intersectionalities which operate below the level of discourse, producing nationalist responses to the international call-out. In doing so, I offer these spectacles as sites where affects are recoded as viewers absorb and remediate them online.

By analyzing these social media posts, I find that publics interpellated by the spectacle engage in performative recodings of popular culture. Through intertextual references, memes, and jokes, Internet users grapple with representations of national failure on what many referred to as the "international" or "global stage." The performative acts of not only the journalist and interviewees, but Internet users, reveal an affective investment in the national spectacle, implicit in the way that posts rearticulate and recode what has been labeled embarrassing, shameful, or worthy of pride to match their own local investments. These posts are recirculated by other national publics and related to local issues of corruption and socioeconomic inequality, as well as affects like shame around the transnational publicity that digital media produces. These practices point to broader structures of feeling which span the national and tether together new kinds of transnational publics through shared forms of affect.

This project provokes questions of independence around countries in the Global South, like Lebanon, which are imbricated in circuits of transnational capital inextricable from colonial and imperial legacies. While narratives of independence and sovereignty are continuously revived on nationalist terms, spectacles like these and the performative acts they produce reveal the transnational interdependencies which are tethered together by particular affects, such as shame or pride. Identifying such affective investments and their interdependencies creates the grounds for new forms of identification, community, and critique.

\section{References}

Ahmed, S. (2014). The cultural politics of emotion (Second edition). Edinburgh University Press. 
Chun, W. H. K. (2016). Updating to remain the same: Habitual new media. The MIT Press.

Clough, P. T. (Ed.). (2018). The user unconscious: On affect, media, and measure. University of Minnesota Press.

El-Ariss, T. (2019). Leaks, hacks, and scandals: Arab culture in the digital age. Princeton University Press.

Manning, E. (2013). Always more than one: Individuation's dance. Duke University Press.

Papacharissi, Z. (2015). Affective publics: Sentiment, technology, and politics. Oxford University Press.

Schaefer, D. O. (2015). Religious affects: Animality, evolution, and power. Duke University Press.

Schaefer, D. O. (2020). Whiteness and civilization: Shame, race, and the rhetoric of Donald Trump. Communication and Critical/Cultural Studies, 17(1), 1-18. https://doi.org/10.1080/14791420.2019.1667503 


\title{
RECODING AFFECT: DIGITAL PYROPOESIS \& EXTREMIST EXPRESSION
}

\author{
Marwan Kraidy \\ Northwestern University Qatar
}

This paper develops the notion of digital pyropoesis-meaning-making by fire via digital means. More specifically, it explores how digitally mediated fire enables a recoding of affect. To do so, IO develop a critical humanistic framework from a combination of elemental philosophy, actor-network theory, and affect theory, which I apply to primary texts produced by the organization that calls itself "Islamic State" and collected as part of a book project on extremism, affect and elementalism. Based on this close reading of several Arabic-language videos and pamphlets produced by Islamic State (see "primary sources" in references), this paper concludes that the potency of extremist agitprop resides in its ability to recode affects via digital pyropoesis.

Fire has as a peculiar capacity to stir our imagination and alter our perception. A stimulus to the imagination, the flame is "one of the greater operators of images," wrote the French chemist and philosopher Gaston Bachelard (1949, 1961). Contemporary writers have likened the magic of cinema to fire's capacity to beguile (Moore, 2000). Others have equated the rise of the internet itself to a rediscovery of fire (Anderson, 2011). If fire, as Lévi-Strauss has shown, is culture's tool to shape nature (fire hardens spear tips, warms up cold caves, cooks raw meat), in this paper I explore how fire is as importantly an instrument to switch sentiment, to disrupt affective experiences and reorient us towards different, often antagonistic feelings. Fire, I argue, is a potent recoder of affect.

In the distinction in Actor-Network-Theory between intermediary and mediator (Callon, 1991; Latour, 2005; Sayes, 2014), fire is a mediator (see also Candea, 2018). An intermediary links various actants in a network in predictable patterns-a given input leads to an expected output; in contrast, a mediator transforms the relationship between actants and leads to contingent, unpredictable outputs. This important insight can be adapted to our discussion of fire. The flame not only induces reverie and ignites our imagination. It also, as Bachelard (1949) put it, avers a longing to "brusque time," and lights up a desire for radical transformation. As an affective catalyst, fire is therefore an ideal medium for stark worldviews. It can serve as a social accelerant that mobilizes and polarizes. The flame can help forge a dualistic, self-versus-other identity. Spun in words and images, flames pop up in pivotal you-are-with-me-or-against-me moments in my primary sources.

For example, in Shield Yourselves and Your Families from a Fire, a video released in May 2016 by Islamic State as part of a moral campaign against satellite dishes, begins with a flame circling a boy on his knees before a television set, and ends with a preacher threatening "Crusaders" who push satellite dishes on Muslims, to meld the antennas into "shrapnel" that "will tear your bodies asunder." The satellite dish is what Sara Ahmed would call a "sticky" object—it attracts and aggregates affect. But rather than being what Ahmed discussed as "happy" objects, the dish is an unhappy thing that 
accrues negative affect. Why does Shield Yourselves begin with a flame guarding a child and end with missiles melded from dishes? Why the rush from shield to shrapnel? This paper answers: because such a switch affirms "Islamic State's" life-or-death, Manichean ethos, and fire is a superb affective linchpin of that mindset.

A fundamental insight ensues: In IS propaganda, a projectilic affect-the feeling of bodily harm that we experience from images design to cause psychic damage (see Kraidy, 2017) always lurks under a prophylactic veneer-prophylactic images convey community, belonging, and shelter. Harm is inextricably linked to wellness. To defend oneself is to harm the nonself. IS identity exists through its opposite. Death is at the center of life, but a flame of community shimmers over dying and demise. Digital pyropoesis enables the construction of two antagonistic domains: the hearth, which provides shelter and belonging, and the torch, with which the enemy is blasted.

One way to understand the articulation of projectilic and prophylactic images, of constructions of torch and hearth, is to focus on how agitprop manipulates feelings. Fire plays an incredibly powerful role in this grand recoding of affect by making possible slippages between projectilic and prophylactic affects. We can thus better understand why the atrocious burning of a human being is framed as a soothing spectacle (in Healing the Believers' Chests), why scenes of belonging end up with the symbolic violence of passport burning (in What Are You Waiting For?), and why the flame turns from shield of childhood to shrapnel tearing the enemy apart (in Shield Yourselves and Your Families from a Fire).

The paper shows how fire stirs and steers feelings. In primary sources, objects of desire, like the satellite dish, become sources of repulsion: once a gateway to fun, the satellite dish grows into a portal of evil. The cinematographers of the Caliphate framed an abominable immolation as a healing spectacle. Iraqi satirists ridiculed caliphal grandiosity and recast fear as fun. The dish and other insignia transmute feelings. Fire's ability to switch emotions makes it a potent binding agent for shaping extreme collective identities - from "Islamic State" to White Power militants, which I will discuss comparatively in my conclusion-and expressing their worldviews.

\section{Primary Sources}

What Are You Waiting For? (2014, November 19). Al-Hayat Media Center [Video, French].

Healing the Believers' Chest (2015, February). Al-Hayat Media Center [Video, English]. Protect Yourself and Your Family from the Fire (2017). Al-Khayr Province [Video, Arabic].

\section{Secondary Sources}

Ahmed, S. (2014). The Cultural Politics of Emotions, $2^{\text {nd }}$ Ed. Edinburgh: Edinburgh University Press. 
Ahmed, S. (2010). "Happy Objects." In M. Gregg \& G. I. Seigworth (Eds.), The Affective Theory Reader (pp. 29-51). Durham, NC: Duke University Press.

Anderson, C. (2011). "The Rediscovery of Fire," In John Brockman (Ed.), Is the Internet Changing the Way You Think? The Net's Impact on our Minds and Future (35-37). New York: Harper Collins.

Bachelard, G. (1949). La psychanalyse du feu. Paris: Gallimard

Bachelard, G. (1961). La flamme d'une chandelle. Paris: Presses Universitaires de France.

Callon, M. (1991). "Techno-economic networks and irreversibility," In J. Law (Ed.), A sociology of monsters: Essays on power, technology and domination (132-165). London: Routledge.

Candea, M. (2008). Fire and Identity as Matters of Concern in Corsica, Anthropological Theory, 8(2), 201-216.

Hansen MBN (2006) New Philosophy for New Media. Cambridge, MA: MIT Press.

Hillis K, Paasonen S and Petit M (eds) (2015) Networked Affect. Cambridge: The MIT Press.

Kraidy, M. M. (2017). The Projectilic Image: Islamic State's Digital Visual Warfare and Global Networked Affect, Media, Culture \& Society, 39(8).

Latour, B. (2005). Reassembling the Social: An Introduction to Actor-Network-Theory. Oxford: Oxford University Press.

Moore, Rachel O., Savage Theory: Cinema as Modern Magic (Durham, NC: Duke University Press, 2000), 121.

Papacharissi, Zizi (2015). Affective Publics: Sentiment, Technology and Politics. New York: Oxford University Press.

Peters, J. D (2015). The Marvelous Clouds: Toward a Philosophy of Elemental Media. Chicago: University of Chicago Press.

Sayes, E. (2014). Actor-Network-Theory and methodology: Just what does it mean to say that nonhumans have agency? Social Studies of Science, 44(11), 134-149. 


\title{
FEELING AL-ANDALUS ONLINE
}

\author{
Omar Al-Ghazzi \\ London School of Economics and Political Science
}

This paper examines the Arab digital culture of remembrance of Al-Andalus, the Arabic name given to Muslim-ruled Spain (which lasted roughly from 711-1492). It argues that affective engagement with history gets pronounced in digital mediation, as meaningmaking processes are destabilised, and traditional gatekeepers of the past are increasingly challenged and side-lined.

My interest is in the politics of nostalgic engagement with Al-Andalus as a new generation of Arabs, inspired by online clerics, turn to social media to express historic sentiment. Through textual and discursive analysis of social media pages, as well as interviews with bloggers and social media administrators, I tell the story of how online Al-Andalus enthusiasts were inspired by the cassette tapes and media productions of celebrity clerics, who popularized Al-Andalus as a central node in Arab Muslim identity. My empirical focus is on how celebrity clerics moved online and retold the story of AlAndalus in a digital space and how those productions and interactions inspired ordinary users to take the lead and become Al-Andalus social media activists in the period 20102020 - tracing the continuities and ruptures in how Al-Andalus was interpreted.

The social media practices that invoke Al-Andalus inspire the formation of online communities and contribute to finding new ways to talk about politics and imagine subjectivity. The administrators of these social media pages share daily posts (texts and images) about a historic period they feel passionate about. Mostly without mentioning sources, they post anecdotes about how life was like in Al-Andalus, the food people ate, the clothes they wore and the weapons they took to battle. They share information about military leaders from that period, in addition to poets and scholars. On par with this highly nostalgic content about the Muslim and Arab past, the administrators often share their "takes" about what is going on today in the Arab world.

The circulation of Al-Andalus on social media has renewed its political shelf life as it moved from its position of a high culture trope in poetry and musicals, with social media, Al-Andalus became more accessible to ordinary users to take the lead in its imagination and reproduction. This Al-Andalus 2.0 is also more Islamically-committed than what was represented in 20th century Arab culture. As I was told in the interviews I conducted, a group of social media activists coordinated their efforts to popularize Al-Andalus online as they were inspired by popular Islamic clerics, (the likes of Egyptian da'iyas Ragheb Al-Sarajani and Amr Khaled), who were pioneers in the efforts to make Arab Muslims feel direct affinity to Islamic history and to express that on social media as an affirmation of religiosity and piety.

On social media, practices of meaning-making and emotional expressions and imaginings of Al-Andalus became more participatory as millions of online Arabs partook in nostalgic and sentimental expressions to affirm that Al-Andalus is part of their identity. Since 2010, a network of young Arabs from across the Middle East and North Africa, inspired by online clerics, connected to each other on the Internet and decided to 
spread information in the form of memes, videos and anecdotes that culminated in launching an Al-Andalus craze on social media pages. Their followers became part of an online community that engages in phatic communicative practices of likes, shares and mundane reactions of approval and prayer, as well as sometimes, in making direct political statements. The 2011 uprisings efforts offered an opportunity to amplify their AlAndalus revivalism and allowed for radical imaginings of new futures and fresh interpretations of the past. Furthermore, given heightened state surveillance of social media, blogging and tweeting about Al-Andalus shielded those living under repressive regimes by allowing them to express political opinions and aspiration that may have otherwise captured the attention of authorities.

Politically, new actors took the reins of speaking about Al-Andalus, they needed a way to express a sense of collective belonging outside of a repertoire dominated by states and going beyond established clerics. The administrators of these social media pages, as well as a network that cooperated in producing content from videos to memes to blog posts, in addition to the millions of followers they attracted, found in Al-Andalus a convenient lens through which to view their political and cultural position and to find a voice to express their sense of agency. They sought to demonstrate their connection to Arab-Islamic history and to cultivate a sense of a cultural, religious, and political community under conditions of fast-changing political circumstances and suffocating restrictions on freedoms of expression.

This kind of engagement makes sense in relation to the political environment that post2011 Arabs find themselves in wherein fast-shifting foreign policies are communicated by opinion leaders as rooted in historic identities. Popular understandings of history in the region are engulfed by shifting foreign policy priorities of ruling regimes. Within a complex and shifting geopolitical terrain, where does that leave questions of identity and their relation to history? The answer to the question gives an indication of why many continue to be invested in the idea of Al-Andalus as part of a history they can continue to cherish while staying out of the complexities of current international relations and moving beyond the state as the gatekeeper of historical imagination.

Yet, beyond the extraction of meaning from this widespread engagement with AlAndalus, there is another side to how we encounter history, which is in the realm of how history makes us feel. In the Arab world, intense sentimentality has characterised modern imaginings of Al-Andalus. One reason is its reduction to the moments of its conquest and fall, and the emotive stories that are told about how Muslim leader Tariq bin Ziyad (who lead the initial conquest of the Iberian Peninsula in the $8^{\text {th }}$ century) heroically crossed the narrow sea separating Africa and Europe. The choice of words through which its story is told heightens emotion. Examples are common words like "fateh" (opening) and "suqut" (fall). Like a chameleon of different emotions, Al-Andalus is about the melancholia of loss; the anxiety over being dominated by a foreign power, getting expelled, and forgotten. It is about the idea that even 700 years of history could be erased. It provokes rage over how historic accomplishments were stolen, how Muslims were ethnically cleansed. It also brings joy and pride over past glory; feelings of defiance that Arab Muslims are not intrinsically backward; and the hope in the sense of possibility that historic glories could be revived. While one feeling may dominate depending on present political circumstances, these contradictory sentiments have long 
co-existed and they clearly manifest themselves on social media as one scrolls through a Twitter page or reads reactions on Facebook. I conclude by showing how these social media pages invite their users and fans to indulge in different expressions of sentimentality that are amplified and intensified as they get shared on different platforms. 


\section{ZANAAKHA: THE TRANSNATIONAL AFFECT OF MEMES}

Sulafa Zidani

Massachusetts Institute of Technology

Memes serve as cultural building blocks that bridge between personal and political meanings (Shifman, 2014), between the past and present (Hristova, 2013), and between seriousness and silliness or politics and humor (Mina, 2019; Shifman, 2014; Tay, 2014). Thus, it is no surprise that questions related to worldview, hope, aspirations, and self-awareness hop on the vessel of memes. With the exception of regional case studies that address cultures separately (Makhortykh and González Aguilar, 2020; Szablowicz, 2014), scholarship investigating Internet memes and affect from a transnational perspective is so far limited.

This paper looks into memes that mix languages (including: Mandarin Chinese, Arabic, Hebrew, English, French, Spanish) as well as interviews with international meme makers to examine the relationship between affect and humor in Internet memes. The importance of studying affect in memes lies in the potential for affect to be a locus for cultural and political theories (Deleuze and Guattari, 1983 ; Seigworth and Gregg, 2010).

I build on Scablowicz's analysis of the diaosi meme in China, and her conceptualization of memes as "structures of feeling" (as per Williams, 1977), and apply this type of analysis to a transnational level that also examines multiple memes rather than a single one, and incorporates data from interviews with meme makers. This analysis contributes to a better understanding of the structures of feeling in which global meme makers (usually youth, broadly defined between the ages of 16-35) are operating.

There is a certain type of affect that comes through when we look at memes globally that can teach us about the generation of youth that is making and circulating these memes. This is an affect of self-awareness, defeat, extraneousness, and a type of humor which I am calling zanaakha-a cheesy or kitschy humor that is not trying to be edgy or creative. In what comes below, I outline some of the findings of the study under three themes: Independence, zanaakha, and extraneousness. I conclude with a brief discussion on the stakes and implications of these findings.

\section{The Independence of the Fictional Space}

Despite-or perhaps because of - the clear connection between online and offline worlds, meme makers I interviewed saw a unique opportunity in online expression through memes. In the words of one of my interviewees, Hadeel: "Our everyday context that we live in is oppressive, as opposed to the fictional context [of memes and popular culture]." Hadeel invoked the 1996 Declaration of the Independence of Cyberspace in which John Perry Barlow speaks of the Internet as a space where nation-states have no authority and cannot impose their rules (Barlow, 1996). "Globalization ignores my specific oppressive context." Hadeel said, "It just makes me think: is the fictional space the place where we can make change?" 


\section{The Humor and Affect of Zanaakha: Defeated Kitsch}

Below are a few examples of the memes I examined combining different cultures and languages.

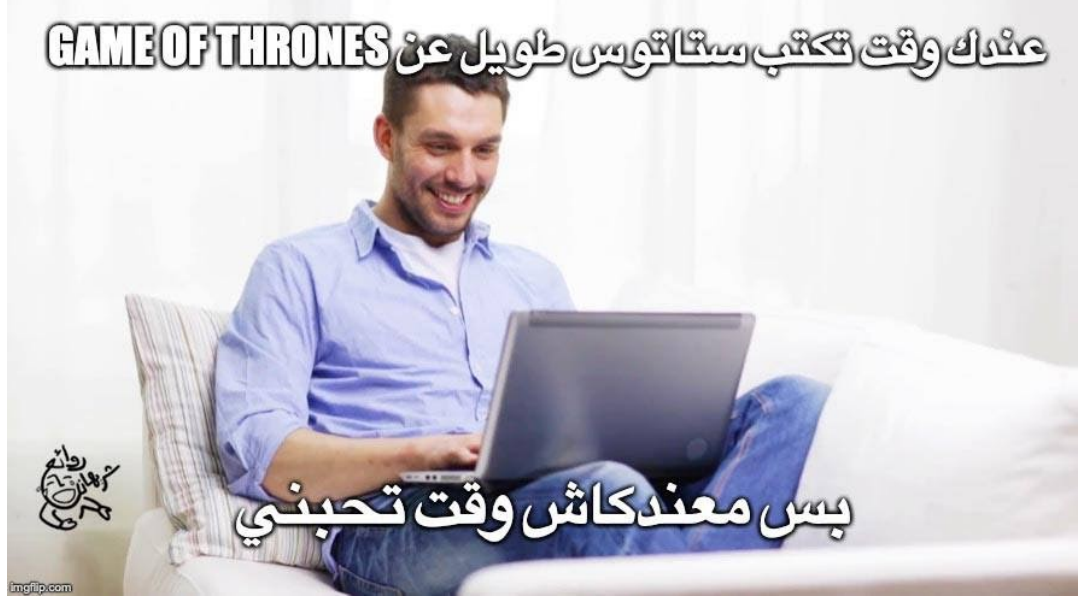

"You have time to write a long [Facebook] status on Game of Thrones, but you don't have time to love me."

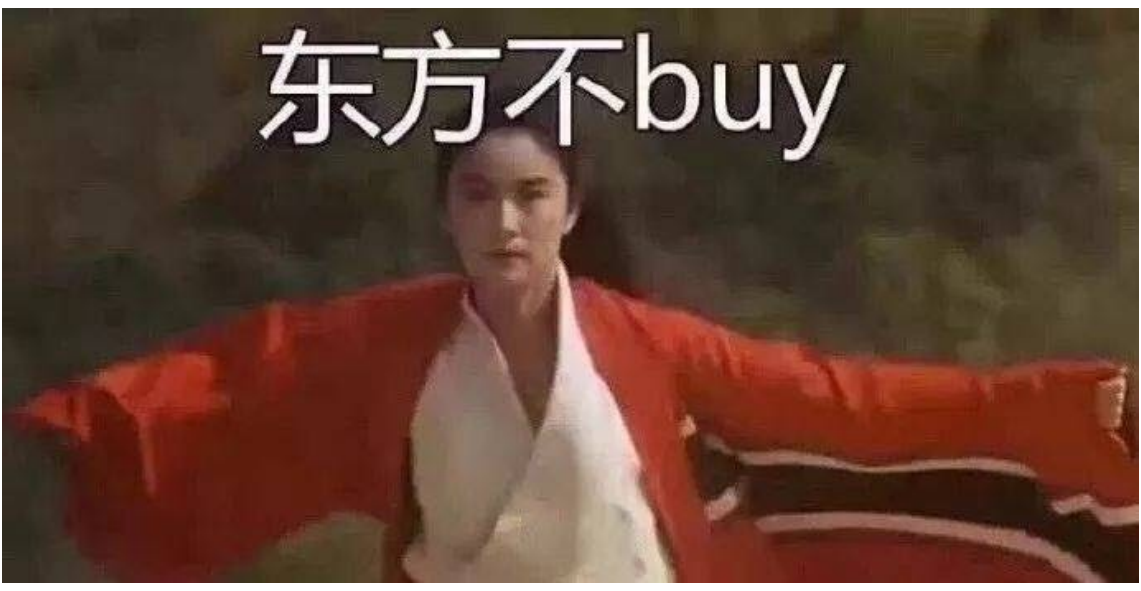

The Invincible East 东方不败 (Dōngfāng Búbài) is a fictional character from the martial arts novel The Smiling, Proud Wanderer by Jinyong. This meme draws on Dongfang

Bubai's name and formidable martial arts skills to create a pun about relentless shopping to November $11^{\text {th }}$ (Singles' Day), an unofficial holiday in China usually celebrated with big sales and shopping. 


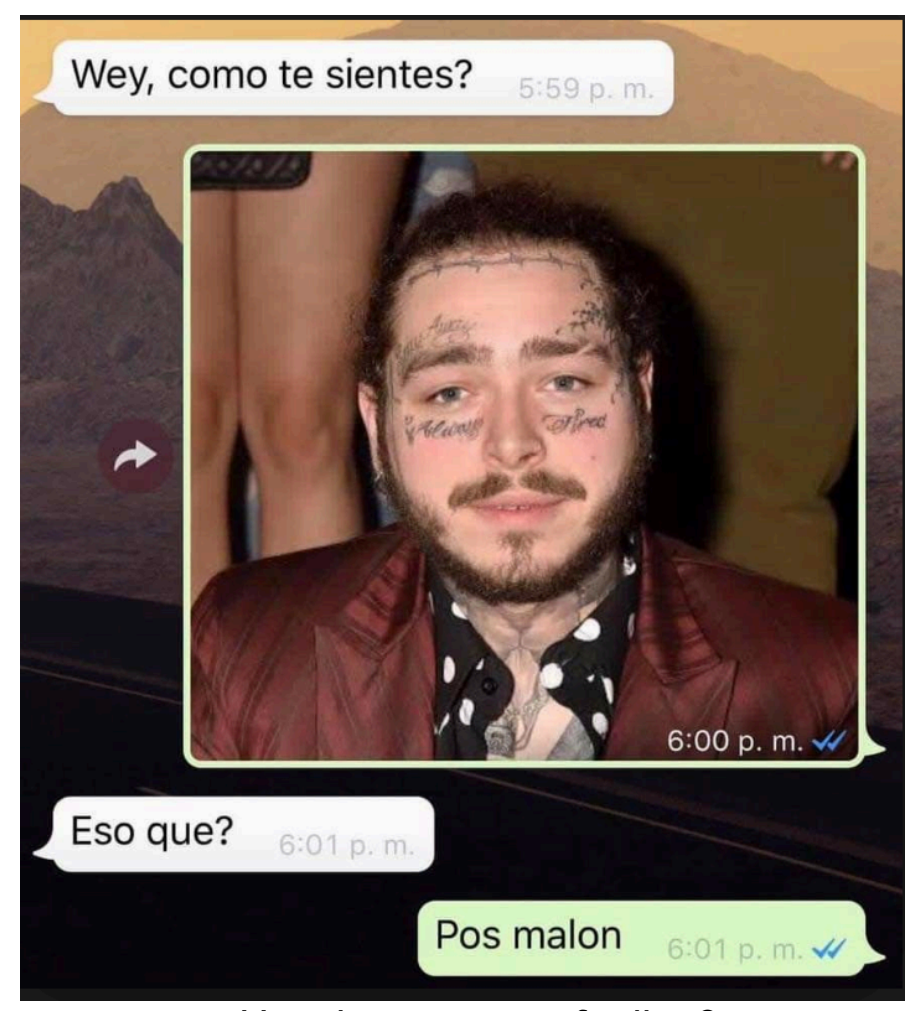

- Hey, how are you feeling?

- [image of American singer Post Malone]

- What's that?

- Kind of bad. [sounds like Post Malone]

The humor of the memes I examined is a self-aware kitschy humor. It is a type of humor that is not always trying to be edgy, but rather often basks in its kitsch. At the same time, this humor carried along with it an affect of defeat or powerlessness. This defeat is similar to what Szablewicz explains in her work on the diaosi memes, whereby Internet users use the meme/term diaosi (loser) to articulate their desired-yet-unachievable lifestyles due to economic uncertainty (Szablewicz, 2014). The meme makers turn that defeat into cheesy jokes in their memes to laugh at their situations like lost love, shopping crazes, or bad feelings. I use the colloquial Arabic term zanaakha to refer to this type of humor since it encapsulates both the kitschy humor and the defeated affect in one term. Zanaakha is a type of humor that is aware of its almost annoyingly cheesy nature, and that is what leads to laughter.

\section{Extraneous but Involved}

Interviewees expressed feeling neither here nor there, or somewhere in between. Many identified as marginalized, oppressed, outsiders in their own communities, or third culture kids. Despite feeling extraneous, they also expressed an air of pride and confidence in who they are and in their multilinguistic meme production. "This is what we're like" said Sharihan, a meme maker from Haifa. Hager, who makes memes with her sister, said that mixing languages is "more true to who we are." The admin of the page LGBTQ Sarcasm Society expressed that, in their meme creation, they aim for "something beyond laughter." That which is beyond laughter refers to making a point 
about culture, religion, gender, and politics. It is about changing people's minds and opinions, and raising awareness.

\section{Is this... Activism?!}

The global rhythm of memes is punctuated by cultural trends dominated by American meme trends and media culture. Despite their global nature, multilinguistic memes include scenes from films and TV shows or music videos and meme templates that come predominantly from the United States. However, multilinguistic meme makers transform these punctuations into punctures or interventions, communicating their own voices of critique, humor, and desire for change. The affect of defeat that is in the zanaakha of these memes might seem counterproductive to civic efforts. However, to circle back to Hadeel's question about whether or not the fictional space can be an independent space for change, I argue that zanaakha has a purpose here. Its low effort and seemingly low stakes affect can lift the pressure of extraneousness and oppression that meme makers expressed to feel in reality and create a space for negotiation, critique, and push for a culture that is more just, without double standards, and a world where they are able to lead the life they want outside of economic precarity. The full paper will unpack the dual relationship to extraneousness which, on one hand, can create isolation, but on the other hand benefits meme makers by creating a safe and exclusive space that they may wish to maintain. What is clear, however, is that, although they use the fictional space independently, meme makers hope to see lasting change across the board.

\section{References}

Barlow, J. P. (1996, February 8). A Declaration of the Independence of Cyberspace [web page]. Available at: https://www.eff.org/cyberspace-independence

Deleuze, G. \& Guattari, F. (1983). Anti-Oedipus: Capitalism and Schizophrenia. Trans. R. Hurley, M. Seem, \& H. R. Lane. Minneapolis: University of Minnesota Press.

Hristova, S. (2013). Occupy wall street meets occupy Iraq: On remembering and forgetting in a digital age. Radical History Review, (117), 83-97.

Makhortykh, M., \& González Aguilar, J. M. (2020). Memory, politics and emotions: internet memes and protests in Venezuela and Ukraine. Continuum, 34(3), 342-362.

Seigworth, G. J., \& Gregg, M. (2010). An inventory of shimmers. In J. Seigworth \& M. Gregg (Eds.), The affect theory reader (pp. 1-25). Duke University Press.

Shifman, L. (2014). Memes in digital culture. Cambridge: MIT Press.

Szablewicz, M. (2014). The 'losers' of China's Internet: Memes as 'structures of feeling' for disillusioned young netizens. China Information, 28(2), 259-275. 
Tay, G. (2014). Binders full of LOLitics: Political humour, internet memes, and play in the 2012 US Presidential Election (and beyond). European Journal of Humour

Research, 2(4), 46-73. https://doi.org/10.7592/EJHR2014.2.4.tay

Williams, R. (1977). Marxism and Literature. New York: Oxford University Press. 